American Journal of Applied Sciences 5 (10): 1415-1423, 2008

ISSN 1546-9239

(C) 2008 Science Publications

\title{
Kinetics of Manganese Uptake by Wetland Plants
}

\author{
A.E. Ghaly, A. Snow and M. Kamal \\ Department of Process Engineering and Applied Science \\ Dalhousie University, Halifax, Nova Scotia, Canada
}

\begin{abstract}
The aim of this study was to assess the kinetics of Mn removal by broad-leaved cattail, soft stem bulrush, soft rush and wool grass plants from contaminated wastewater under laboratory conditions. The approach used was based on a first order kinetic model which depended on the initial heavy metal concentration in the wastewater and allowed for the evaluation of the specific metal uptake rate and the maximum specific content of the metal in each plant species. The results showed that the model is capable of predicting the experimental data with relatively high confidence $\left(\mathrm{R}^{2}=0.88\right)$. The specific Mn uptake rate and the maximum amount of $\mathrm{Mn}$ that can accumulate in each plant species were affected by the initial Mn concentration in the wastewater and the plant species. As the initial concentration of $\mathrm{Mn}$ in the water increased, the specific $\mathrm{Mn}$ uptake rate of each species decreased showing signs of toxicity. Broad-leaved cattail displayed the highest specific Mn uptake rates followed by soft stem bulrush, soft rush and wool grass. The maximum amount of Mn that accumulated in each species also increased as the initial Mn concentration in the wastewater increased. Broad-leaved cattail and soft stem bulrush plants would accumulate the highest amount of Mn in their tissues followed by soft rush and wool grass.
\end{abstract}

Key words: Wetland, aquatic plants, manganese, kinetics, uptake rate, maximum concentration

\section{INTRODUCTION}

Heavy metal pollution of both surface and groundwater is a serious environmental problem that threatens human health and the environment. Unlike organic contaminants, metals do not undergo physical, chemical or microbial degradation and, therefore, require removal for water decontamination ${ }^{[1]}$. Various remediation methods exist for heavy metal contaminated wastewaters. These methods involve chemical approaches such as alkaline precipitation, sulphide precipitation, addition of oxidizing agents and coagulation/flocculation in combination with physical sedimentation and/or filtration processes to remove the metal precipitates from the wastewater ${ }^{[2-4]}$. Physical mechanisms that directly remove dissolved heavy metals from wastewaters include ion exchange ${ }^{[5,6]}$, liquid-liquid extraction ${ }^{[7,8]}$, electrolysis ${ }^{[9,10]}$ and adsorption $^{[11,12]}$.

Aquatic plants are plants that must complete part or all of their life cycle in or near the water. There are three kinds of aquatic plants: (a) submersed plants, which grow beneath the water surface, (b) marginal plants, which root below but extend above the water surface and (c) floating plants, which are not anchored to the soil but float freely at the water surface. The ability of aquatic plants to absorb and accumulate metals from their aquatic environment has been demonstrated by a number of researchers ${ }^{[13-17]}$. The degree of metal uptake by plants is largely dependent on the type of metal and the plant species involved.

Constructed wetlands are inexpensive systems for wastewater treatment and have been used to treat heavy metal contaminated wastewaters. There are a number of processes that naturally exist in wetlands for heavy metal removal including sedimentation and filtration of solids, chemical precipitation, ion exchange, adsorption, biological assimilation, volatilization and plant uptake ${ }^{[18]}$. Aquatic plants in the wetland are extremely important for nutrient transformations and transfers because they play a key role in the cycling and temporary storage of many substances and provide habitat and energy sources to maintain a diverse microbial population in the sediments ${ }^{[19,20]}$.

Corresponding Author: A.E. Ghaly, Professor, Department of Process Engineering and Applied Science, Dalhousie University Halifax, Nova Scotia, Canada, Tel: (902)494-6014 
It is, therefore, important to understand the uptake of metals in wetland plants.

The aim of this study was to assess the performance of selective facultative and obligate wetland plants for the removal of $\mathrm{Mn}$ from contaminated wastewater by examining the manganese uptake kinetic parameters of each plant species. The specific objectives of in this study were to determine the concentration of manganese in the plants the specific metal uptake rate for each plant and the maximum concentration of manganese that each plant could accumulate.

\section{Experimental Apparatus}

The experimental setup shown in Fig. 1 consists of holding tanks and lighting and aeration systems.

Four boxes were constructed from $2.5 \mathrm{~cm}$ thick plywood. Each box $(60 \times 120 \times 80 \mathrm{~cm})$ was divided into three compartments $(30 \times 60 \times 80 \mathrm{~cm}$ each) and each compartment contained a holding tank.

The light was provided by an artificial lighting system $\left(625\right.$ hectolux $\left./ 7200 \mathrm{~cm}^{2}\right)$ and was similar to the natural light required for wetland plants. Each lighting unit consisted of eight light bulbs (six 34 watts cool white fluorescent bulbs and two Gro-lux 40 watts bulbs) of $122 \mathrm{~cm}$ in length. The lighting system was placed on the top of each box using wooden supports in such a way that it gave a space of $140 \mathrm{~cm}$ clearance between the light bulbs and the water surface in the box. This space was chosen to achieve good air circulation and provide the heat and light that were required for plant growth. The lights were controlled by a timer, which was set to provide 16 hours of light per box per day and to maintain a temperature difference between the soil and the above ground part of $15^{\circ} \mathrm{C}^{[21]}$.

An aeration unit was installed in the bottom of each compartment to provide oxygen for the plants. The air traveled from the main laboratory supply to a manifold with twelve outlets. Each outlet was connected to a pressure regulator (Model 129121/510, ARO, Bryan, Ohio), which was connected to an aerator located in each compartment. Each aerator consisted of a main tube $(26.5 \mathrm{~cm}$ long) with three perforated stainless steel laterals $(30 \mathrm{~cm}$ in length and $0.6 \mathrm{~cm}$ in diameter) coming off it at right angles to the main. Tygon tubing of $0.75 \mathrm{~cm}$ outside diameter was used to connect the main air supply, manifold and aeration unit. The pressure regulator was adjusted at 0.068 atm during the whole experimental period to give an aeration rate of 7 $\mathrm{cm}^{-3} \mathrm{~min}^{-1}$.

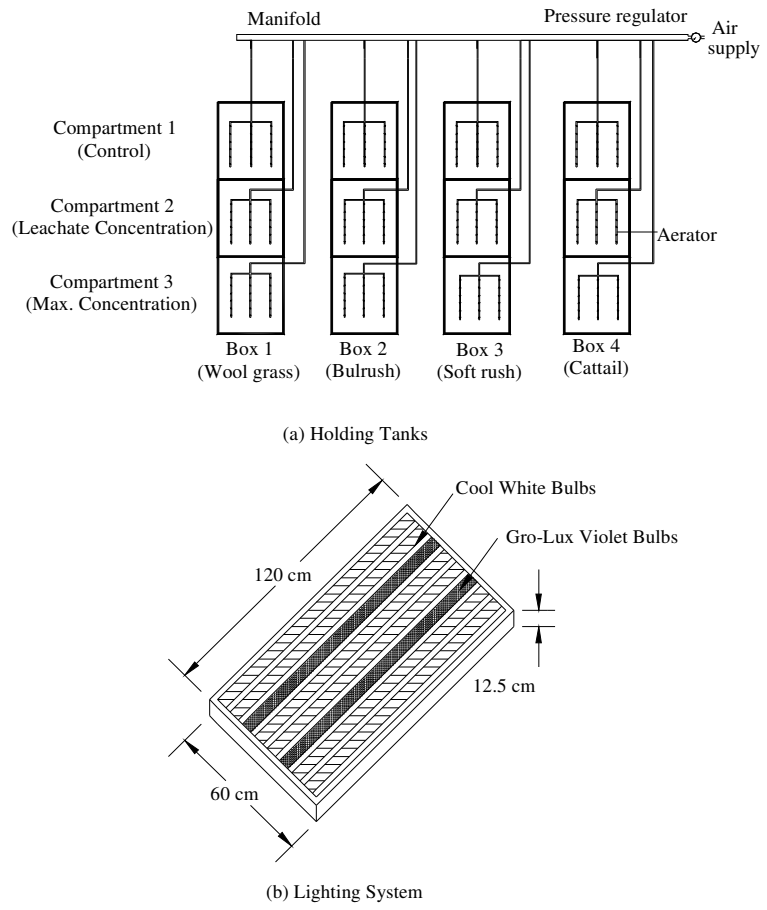

Fig. 1: Experimental apparatus

\section{Experimental Procedure}

Wetland plants: Two facultative (wool grass and soft rush) and two obligate (broad-leaved cattail and soft stem bulrush) wetland plant species were used in the study. The selection of these plants was based on their dominance in the constructed wetland ${ }^{[22]}$. Both soft rush and soft stem bulrush have been listed in many references as both obligate and facultative wetland plants. These wetland plants were obtained from Environmental Concern Inc., St. Michaels, Maryland, USA.

Contaminant preparation: The plants were supplied with nutrients using a fertilizer (20-20-20 Plant-Prod, Plant Products Co. Ltd., Brampton, Ontario) at a rate of $817 \mathrm{mg}$ of fertilizer per $1 \mathrm{~L}$ of water. Manganous sulfate $\left(\mathrm{MnSO}_{4} \cdot \mathrm{H}_{2} \mathrm{O}\right)$ was used as a contaminant supply of manganese. This compound was purchased as a reagent grade chemical from Fisher Scientific, Ottawa, Ontario. Two manganese concentrations were selected: (a) one concentration to simulate manganese concentrations in the influent of a constructed wetland treating landfill leachate ${ }^{[23]}$ and (b) the other concentration to represent the highest manganese tolerance concentration reported in the literature ${ }^{[19]}$. $\mathrm{MnSO}_{4} \cdot \mathrm{H}_{2} \mathrm{O}$ was dissolved in distilled water to achieve 
Am. J. Applied Sci., 5 (10): 1415-1423, 2008

Table 1: Concentrations of manganese $\left(\mathrm{mg} \mathrm{L}^{-1}\right)$ in the water

\begin{tabular}{lcrr}
\hline Element & Control & Leachate & Tolerance \\
\hline Nutrient & & & \\
Potassium & 163.40 & 163.40 & 163.40 \\
Nitrogen & 163.40 & 163.40 & 163.40 \\
Phosphorus & 163.40 & 163.40 & 163.40 \\
EDTA & 8.17 & 8.17 & 8.17 \\
Boron & 0.16 & 0.16 & 0.16 \\
Sulfur & ----- & 8.60 & 123.21 \\
Heavy metals & & & \\
Iron & 0.82 & 0.82 & 0.82 \\
Manganese & 0.41 & 2.21 & 15.41 \\
Copper & 0.41 & 0.41 & 0.41 \\
Zinc & 0.41 & 0.41 & 0.41 \\
\hline & & &
\end{tabular}

the appropriate contaminant level. A control with tap water was also used in the study. The final concentrations of manganese used in this experiment are presented in Table 1.

Experimental protocol : A $10 \mathrm{~cm}$ layer of large gravel $(1.25 \mathrm{~cm}$ average nominal size) was placed in each compartment to facilitate the collection of drainage water. A $35.5 \mathrm{~cm}$ long drainage tube, with holes in the lower $10 \mathrm{~cm}$ end, was placed vertically in each compartment. The drainage tube was connected to a wet vacuum pump (Bulldog 700, Shop-Vac Canada Ltd., Burlington, Ontario) to ensure complete drainage of water before introducing the next batch of contaminated water. Soil was used as a supporting media for the plants. It was placed into each compartment in layers (approximately $10 \mathrm{~cm}$ thick) and lightly compacted to remove excessive voids within the soil structure. One box (three compartments) was used for each plant species. About 8 plants $(20-30 \mathrm{~cm}$ tall) were placed in each of the three compartments in each box. The start up procedure for growing wetland plants in a closed system followed that described by Mills ${ }^{[21]}$. The water level in each compartment was maintained below the root system of the plants while keeping the soil around the root system moist at all times. The plants were sprayed with the insecticide Malathion 500EC (The Solaris Group, Mississauga, Ontario) every week to control the spread of aphids in the system. The dilution rate recommended by the manufacture was followed $(2.5 \mathrm{~mL}$ of Malathion was mixed in $1 \mathrm{~L}$ of water). After the startup period of 4 weeks, the experiment was run for 72 days.

The first compartment in each box was used as a control and received $30 \mathrm{~L}$ of tap water containing fertilizer, the second compartment received $30 \mathrm{~L}$ of contaminated water containing fertilizer and a $\mathrm{Mn}$ concentration similar to that of the influent of the constructed wetland and the third compartment received
$30 \mathrm{~L}$ of contaminated water containing fertilizer and a Mn concentration similar to that reported in the literature as the highest tolerance level for the four plants. The wastewater was changed every 9 days to simulate the retention time of the water in the constructed wetland ${ }^{[22]}$.

Sampling and analyses : Plant samples were collected from all compartments at 9 day intervals and analyzed for manganese. The plant samples (root, stem, leaf, and flower) were dried in a convection oven for 24 hours at $45^{\circ} \mathrm{C}$. After drying, the plant samples were ground and digested with hydrochloric-nitric-hydrofluric-perchloric acids $\left(30+10+10+5 \mathrm{~mL} \mathrm{~g}^{-1}\right.$ sample) in a closed vessel at a temperature of $100^{\circ} \mathrm{C}$. The $\mathrm{Mn}$ concentration was determined using an atomic absorption spectometer (Varion SpectrAA, Model Number: 55B, Varion, Mulgrave, Victoria, Australia).

\section{RESULTS AND DISCUSSION}

Mn concentration: Table 2 displays the average initial Mn concentrations in each species at the beginning of the experiment $(\mathrm{t}=0)$ and the total amount of manganese accumulated by each species throughout the experiment. The results showed that as the initial concentration of manganese in the wastewater increased, the concentration of manganese in each species also increased. At the end of the experiment, the highest amount of manganese in the total plant tissues was in soft stem bulrush with concentrations of 1202 , 957 and $709 \mathrm{mg} \mathrm{kg}^{-1}$ followed by soft rush with concentrations of 1001,845 and $689 \mathrm{mg} \mathrm{kg}^{-1}$, cattail with concentrations of 910,838 and $776 \mathrm{mg} \mathrm{kg}^{-1}$ and wool grass with concentrations of 921,649 and $370 \mathrm{mg}$ $\mathrm{kg}^{-1}$ for the compartments receiving tolerance concentration, landfill leachate and control, respectively.

Samecka-Cymerman and Kempers ${ }^{[24]}$ examined the concentrations of heavy metals in aquatic macrophytes from anthropogenic lakes on former open cut brown coal mine sites and found that the concentration of $\mathrm{Mn}$ in the leaves of soft rush varied from $123 \pm 11$ to $1500 \pm 82 \mathrm{mg} \mathrm{kg}^{-1}$. Collins et al. ${ }^{[25]}$ examined the element concentrations in plants growing in a constructed wetland that was receiving metal contaminated effluent from a coal pile runoff basin and found that the average concentration of $\mathrm{Mn}$ in the roots and shoots of soft rush were 571 and $596 \mathrm{mg} \mathrm{kg}^{-1}$, respectively. Demirezen and Aksoy ${ }^{[26]}$ examined the concentrations of heavy metals in aquatic plants growing in a polluted marsh and found that the 
Am. J. Applied Sci., 5 (10): 1415-1423, 2008

Table 2: Concentration of manganese in plant tissues

\begin{tabular}{|c|c|c|c|c|c|}
\hline \multirow[b]{2}{*}{ Time } & \multirow[b]{2}{*}{ Compartment } & \multicolumn{3}{|c|}{ Concentration $\left(\mathrm{mg} \mathrm{kg}^{-1}\right)$} & \multirow[b]{2}{*}{ Cattail } \\
\hline & & Bulrush & Wool grass & Soft rush & \\
\hline$\overline{0}$ & Initial Mn & 385 & 134 & 422 & 273 \\
\hline \multirow[t]{3}{*}{9} & Tolerance & 583 & 223 & 635 & 512 \\
\hline & Leachate & 491 & 210 & 543 & 396 \\
\hline & Control & 411 & 138 & 466 & 435 \\
\hline \multirow[t]{3}{*}{18} & Tolerance & 705 & 307 & 643 & 596 \\
\hline & Leachate & 543 & 249 & 545 & 438 \\
\hline & Control & 477 & 167 & 455 & 475 \\
\hline \multirow[t]{3}{*}{27} & Tolerance & 770 & 380 & 691 & 654 \\
\hline & Leachate & 600 & 296 & 595 & 504 \\
\hline & Control & 534 & 184 & 486 & 427 \\
\hline \multirow[t]{3}{*}{36} & Tolerance & 888 & 491 & 784 & 690 \\
\hline & Leachate & 648 & 383 & 672 & 522 \\
\hline & Control & 524 & 218 & 526 & 488 \\
\hline \multirow[t]{3}{*}{45} & Tolerance & 987 & 569 & 798 & 718 \\
\hline & Leachate & 740 & 407 & 721 & 619 \\
\hline & Control & 599 & 245 & 572 & 540 \\
\hline \multirow[t]{3}{*}{54} & Tolerance & 1024 & 662 & 867 & 789 \\
\hline & Leachate & 760 & 477 & 746 & 702 \\
\hline & Control & 638 & 290 & 605 & 599 \\
\hline \multirow[t]{3}{*}{63} & Tolerance & 1067 & 744 & 919 & 820 \\
\hline & Leachate & 826 & 525 & 801 & 721 \\
\hline & Control & 646 & 333 & 608 & 662 \\
\hline \multirow[t]{3}{*}{72} & Tolerance & 1202 & 921 & 1001 & 910 \\
\hline & Leachate & 957 & 649 & 845 & 838 \\
\hline & Control & 709 & 370 & 689 & 776 \\
\hline \multirow[t]{3}{*}{$\mathrm{Mn} \mathrm{co}$} & ntration & 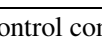 & 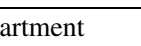 & $=0.4$ & $\mathrm{~g} \mathrm{~L}^{-1}$ \\
\hline & tration & cha & artment & $=2.21$ & $\mathrm{~g} \mathrm{~L}^{-1}$ \\
\hline & tration & 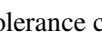 & artment & $=15.41 \mathrm{~m}$ & $\operatorname{g~L}^{-1}$ \\
\hline
\end{tabular}

concentrations of $\mathrm{Mn}$ in the roots and shoots of narrowleaved cattail were approximately 400 and $850 \mathrm{mg} \mathrm{kg}^{-1}$, respectively.

Kinetics of manganese uptake: The approach used in this study is based on a first order kinetic model and depends on the heavy metal concentration in the biomass of the plant. This method enables the evaluation of the specific metal uptake rate and the maximum specific content of the metal in the plant ${ }^{[27]}$.

The uptake of dissolved manganese by an aquatic plant at given conditions ( $\mathrm{pH}$ and temperature) can be expressed as a function of the maximum concentration of manganese that can be accumulated in the plant tissue and the specific uptake rate using the following first-order kinetic model ${ }^{[27]}$.

$$
\frac{d\left(M_{p}\right)}{d t}=k \cdot\left(M_{M}-M_{p}\right)
$$

Where:

$M_{p}=$ Concentration of manganese in the wetland plant at a given time $\left(\mathrm{mg} \mathrm{kg}^{-1}\right)$

$\mathrm{M}_{\mathrm{M}}=$ Maximum concentration of manganese that can be accumulated in the wetland plant during a specific growth period $\left(\mathrm{mg} \mathrm{kg}^{-1}\right)$

$\mathrm{K}=$ Specific uptake rate $\left(\mathrm{d}^{-1}\right)$
Eq. 1 shows that the higher the $\mathrm{k}$-value the faster the manganese absorption by the plants. Eq.1 can be rearranged for integration using the limits $0 \rightarrow M_{p}$ and $0 \rightarrow \mathrm{t}$ as follows:

$$
\int_{0}^{M_{p}} \frac{d\left(M_{p}\right)}{M_{M}-M_{p}}=\int_{0}^{t} k \cdot d t
$$

Where:

$\mathrm{t}=$ time $(\mathrm{d})$

On integration, Eq. 2 can be written as follows:

$$
\ln \left(\frac{M_{M}}{M_{M}-M_{p}}\right)=k \cdot t
$$

Eq. 3 can also be written in a logarithmic form as follows:

$$
2.3 \log \left(\frac{\mathrm{M}_{\mathrm{M}}}{\mathrm{M}_{\mathrm{M}}-\mathrm{M}_{\mathrm{p}}}\right)=\mathrm{k} \cdot \mathrm{t}
$$

Or

$$
\log \left(\frac{\mathrm{M}_{\mathrm{M}}}{\mathrm{M}_{\mathrm{M}}-\mathrm{M}_{\mathrm{p}}}\right)=\frac{\mathrm{k} \mathrm{t}}{2.3}
$$

Eq. 5 can then be transformed to the following equation:

$$
\frac{M_{M}}{M_{M}-M_{p}}=10^{\frac{k t}{2.3}}
$$

The concentration of manganese in the wetland influent was relatively constant over time. Therefore, the value of $\mathrm{k}$ was assumed to be constant. By substituting $\mathrm{r}$ for $\mathrm{k} / 2.3$, Eq.6 can be rearranged as follows:

$$
\mathrm{M}_{\mathrm{p}}=\mathrm{M}_{\mathrm{M}}\left(1-10^{-\mathrm{rt}}\right)
$$

Eqation 7 indicates that the concentration of manganese in the plant at any time is a function of the maximum concentration that can be accumulated in the plant and the specific uptake rate.

Determination of $\mathbf{r}$ and $\mathbf{M}_{\mathbf{M}}$ : Two kinetic parameters ( $r$ and $\mathrm{M}_{\mathrm{M}}$ ) in Eq.7 need to be determined for each plant. If the manganese concentration in the solution 
remains stable, which is the case of the constructed wetland, then $r$ and $M_{M}$ parameters for a wetland plant can be determined. Substituting $M_{1}$ for $M_{p} / M_{M}$ in Eq.7 yields the following equation:

$$
\mathrm{M}_{1}=1-10^{-\mathrm{rt}}
$$

Eq. 8 can also be rewritten in an exponential form as follows:

$$
\mathrm{M}_{1}=1-\mathrm{e}^{-2.3 \mathrm{rt}}
$$

Using Taylor series, a solution for Eq.9 is as follows ${ }^{[28]}$ :

$$
\begin{aligned}
M_{1}= & (2.3 r t)\left[1-1 / 2(2.3 r t)+1 / 6(2.3 r t)^{2}\right. \\
& \left.-1 / 24(2.3 r t)^{3}+\ldots .\right]
\end{aligned}
$$

The Taylor series in Eq.10 is similar to the following binomial series provided by Vlyssides et al. ${ }^{[29]}$ :

$$
\begin{aligned}
M_{2}= & (2.3 r t)\left[1-1 / 2(2.3 r t)+1 / 6(2.3 r t)^{2}\right. \\
& \left.-1 / 24(2.3 r t)^{3}+\ldots .\right]
\end{aligned}
$$

The first three terms in the functions $\mathrm{M}_{1}$ (Eq. 10) and $\mathrm{M}_{2}$ (Eq.11) are similar and the small residue of the rest of the terms will minimally affect $\mathrm{M}_{1}$ and $\mathrm{M}_{2}$. Eq. 11 follows the following binomial series formula ${ }^{[28]}$ :

$$
\begin{aligned}
(a+x)^{n}= & a^{n}+n a^{n-1} x+\frac{n(n-1)}{2 !} a^{n-2} x^{2} \\
& +\frac{n(n-1)(n-2)}{3 !} a^{n-3} x^{3}+\ldots \ldots . .
\end{aligned}
$$

In order to transform the right hand side of Eq. 12 to $\mathrm{M}_{2}$ series (Eq.11), the following conditions were maintained:

$$
\begin{aligned}
& x=\frac{2.3 \mathrm{rt}}{6} \\
& \mathrm{a}=1 \\
& \mathrm{n}=-3
\end{aligned}
$$

Substituting for $\mathrm{x}$, a, and $\mathrm{n}$ values in Eq.12 and multiplying by $(2.3 \mathrm{rt})$ yields the following equation:

(13)

$$
\begin{aligned}
& (2.3 r t)\left[1+\frac{2.3 r t}{6}\right]^{-3}= \\
& (2.3 r t)\left[1^{-3}+\left[(-3)\left[1^{-3-2}\right]\left[\frac{2.3 r t}{6}\right]\right]+\right. \\
& \left.\left[\left[\frac{-3(-3-1)}{2 !}\right]\left(1^{-3-2}\right)\left[\frac{2.3 r t}{6}\right]^{2}\right]+\cdots\right]
\end{aligned}
$$

Or

$$
\begin{aligned}
(2.3 \mathrm{rt})\left[1+\frac{2.3 \mathrm{rt}}{6}\right]^{-3}= & (2.3 \mathrm{rt})\left[1-1 / 2(2.3 \mathrm{rt})+1 / 6(2.3 \mathrm{rt})^{2}\right. \\
& -1 / 21.6^{\left.(2.3 \mathrm{rt})^{3}+\ldots .\right]}
\end{aligned}
$$

Combining Eq.11 and 14 can, therefore, yield the following equation:

$$
\mathrm{M}_{2}=(2.3 \mathrm{rt})\left[1+\frac{2.3 \mathrm{r} \mathrm{t}}{6}\right]^{-3}
$$

Since $\mathrm{M}_{1}=\mathrm{M}_{\mathrm{p}} / \mathrm{M}_{\mathrm{M}}$ (Eq. 7 and 8) and $\mathrm{M}_{1}=\mathrm{M}_{2}$ (Eq. 10 and 11), then Eq. 15 can be rewritten as follows:

$$
\mathrm{M}_{\mathrm{p}}=(2.3 \mathrm{rt})\left[1+\frac{2.3 \mathrm{rt} \mathrm{t}}{6}\right]^{-3} \mathrm{M}_{\mathrm{M}}
$$

The linear form for Eq. 16 is as follows:

$$
\left(\frac{\mathrm{t}}{\mathrm{M}_{\mathrm{p}}}\right)^{1 / 3}=\frac{1}{\left(2.3 \mathrm{r} \mathrm{M}_{\mathrm{M}}\right)^{1 / 3}}+\frac{(2.3 \mathrm{r})^{2 / 3} \mathrm{t}}{6 \mathrm{M}_{\mathrm{M}}^{1 / 3}}
$$

Eq. 17 has the following linear form:

$$
\mathrm{Y}=\mathrm{A}+\mathrm{B} \cdot \mathrm{X}
$$

Where:

$$
\begin{aligned}
& \mathrm{Y}=\left(\mathrm{t} / \mathrm{M}_{\mathrm{p}}\right)^{1 / 3} \\
& \mathrm{X}=\mathrm{t} \\
& \mathrm{A}=\left(2.3 \mathrm{r} \mathrm{M}_{\mathrm{M}}\right)^{-1 / 3} \\
& \mathrm{~B}=\frac{(2.3 \mathrm{r})^{2 / 3}}{6 \mathrm{M}_{\mathrm{M}}^{1 / 3}}
\end{aligned}
$$

The A and B values can be obtained graphically for various plant-metal combinations according to the 
Am. J. Applied Sci., 5 (10): 1415-1423, 2008

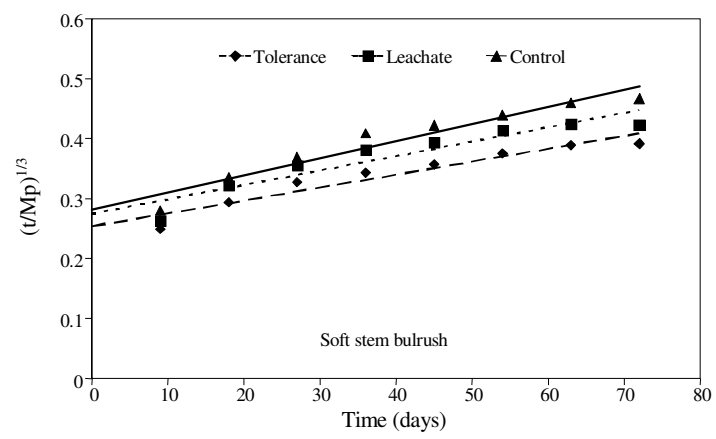

Table 3: Values of A and B in Eq.18

\begin{tabular}{llll}
\hline Plant & Concentration & A & B \\
\hline Broad leaved cattail & & & \\
& Tolerance & 0.2262 & 0.0028 \\
& Leachate & 0.2574 & 0.0026 \\
& Control & 0.2532 & 0.0029 \\
& Wool grass & & \\
& Tolerance & 0.3526 & 0.0016 \\
& Leachate & 0.3611 & 0.0024 \\
Soft stem bulrush & Control & 0.4162 & 0.0030 \\
& & & \\
& Tolerance & 0.2537 & 0.0022 \\
Soft rush & Leachate & 0.2749 & 0.0024 \\
& Control & 0.2824 & 0.0028 \\
& & & \\
& Tolerance & 0.2988 & 0.0020 \\
& Leachate & 0.3137 & 0.0021 \\
& Control & 0.3347 & 0.0024 \\
\hline
\end{tabular}
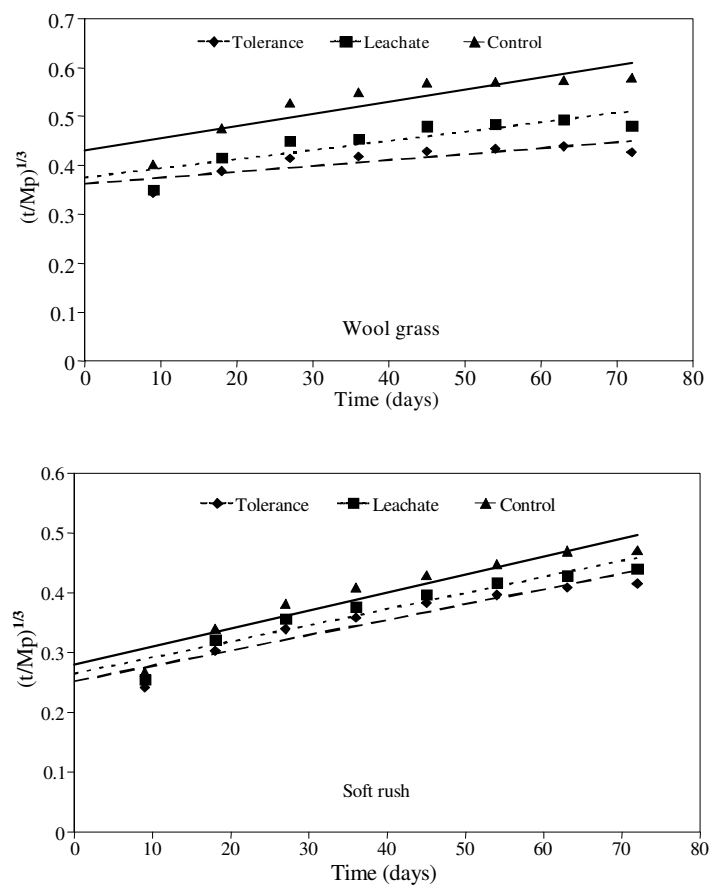

Table 4: Linear form of Eq.18 for manganese uptake

\begin{tabular}{|c|c|c|c|}
\hline Plant & Concentration & Equation & $\mathrm{R}^{2}$ \\
\hline \multicolumn{4}{|c|}{ Broad leaved cattail } \\
\hline & Tolerance & $\left(\mathrm{t} / \mathrm{M}_{\mathrm{p}}\right)^{1 / 3}=0.2262+0.0028 \mathrm{t}$ & 0.94 \\
\hline & Leachate & $\left(\mathrm{t} / \mathrm{M}_{\mathrm{p}}\right)^{1 / 3}=0.2574+0.0026 \mathrm{t}$ & 0.92 \\
\hline & Control & $\left(\mathrm{t} / \mathrm{M}_{\mathrm{p}}\right)^{1 / 3}=0.2532+0.0029 \mathrm{t}$ & 0.90 \\
\hline \multicolumn{4}{|c|}{ Wool grass } \\
\hline & Tolerance & $\left(\mathrm{t} / \mathrm{M}_{\mathrm{p}}\right)^{1 / 3}=0.3526+0.0016 \mathrm{t}$ & 0.82 \\
\hline & Leachate & $\left(\mathrm{t} / \mathrm{M}_{\mathrm{p}}\right)^{1 / 3}=0.3611+0.0024 \mathrm{t}$ & 0.84 \\
\hline & Control & $\left(\mathrm{t} / \mathrm{M}_{\mathrm{p}}\right)^{1 / 3}=0.4162+0.0030 \mathrm{t}$ & 0.82 \\
\hline \multicolumn{4}{|c|}{ Soft stem bulrush } \\
\hline & Tolerance & $\left(\mathrm{t} / \mathrm{M}_{\mathrm{p}}\right)^{1 / 3}=0.2537+0.0022 \mathrm{t}$ & 0.92 \\
\hline & Leachate & $\left(\mathrm{t} / \mathrm{M}_{\mathrm{p}}\right)^{1 / 3}=0.2749+0.0024 \mathrm{t}$ & 0.90 \\
\hline & Control & $\left(\mathrm{t} / \mathrm{M}_{\mathrm{p}}\right)^{1 / 3}=0.2824+0.0028 \mathrm{t}$ & 0.93 \\
\hline \multicolumn{4}{|c|}{ Soft rush } \\
\hline & Tolerance & $\left(\mathrm{t} / \mathrm{M}_{\mathrm{p}}\right)^{1 / 3}=0.2988+0.0020 \mathrm{t}$ & 0.92 \\
\hline & Leachate & $\left(\mathrm{t} / \mathrm{M}_{\mathrm{p}}\right)^{1 / 3}=0.3137+0.0021 \mathrm{t}$ & 0.90 \\
\hline & Control & $\left(\mathrm{t} / \mathrm{M}_{\mathrm{p}}\right)^{1 / 3}=0.3347+0.0024 \mathrm{t}$ & 0.91 \\
\hline
\end{tabular}

Eq.7, 21 and 22 must be solved simultaneously. Eq. 21 can be rearranged as follows:

$$
\mathrm{r}=\frac{1}{2.3 \mathrm{~A}^{3} \mathrm{M}_{\mathrm{M}}}
$$

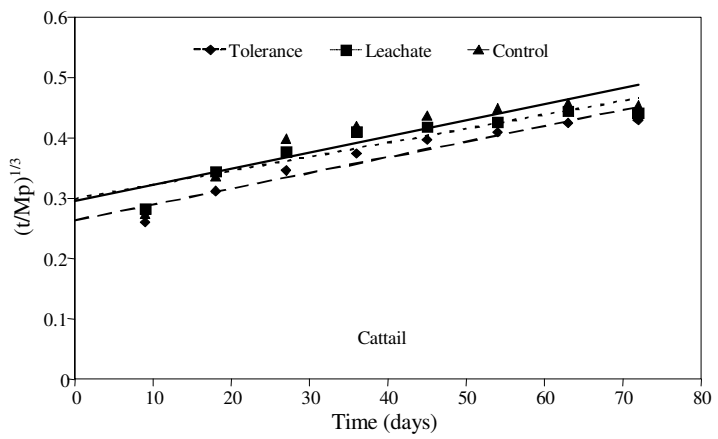

Fig. 2: Graphical determination of A and B for manganese wetland plants

procedure described by Vlyssides et al. ${ }^{[29]}$ by plotting $\left(t / M_{p}\right)^{1 / 3}$ vs. $t$ as shown in Fig. 2. The results are shown in Table 3 and 4 . In order to determine $r$ and $M_{M}$ in

Substituting Eq. 23 in Eq. 22 yields the following equation:

$$
\mathrm{B}=\frac{\left(\frac{2.3}{2.3 \mathrm{~A}^{3} \mathrm{M}_{\mathrm{M}}}\right)^{2 / 3}}{6 \mathrm{M}_{\mathrm{M}}^{1 / 3}}
$$

Equation 24 can be rearranged as follows:

$$
\mathrm{B}=\frac{\left(\mathrm{A}^{-3} \mathrm{M}_{\mathrm{M}}^{-1}\right)^{2 / 3}}{6 \mathrm{M}_{\mathrm{M}}^{1 / 3}}
$$

Or

$$
B=\frac{1}{6 A^{2} M_{M}}
$$


Am. J. Applied Sci., 5 (10): 1415-1423, 2008

Table 5: Manganese kinetic uptake parameters $\left(\mathrm{k}, \mathrm{M}_{\mathrm{M}}\right)$

\begin{tabular}{llll}
\hline Plant & Concentration & $\left.\mathrm{k}^{(-1}\right)$ & $\mathrm{M}_{\mathrm{M}}\left(\mathrm{mg} \mathrm{kg}^{-1}\right)$ \\
\hline Broad-leaved cattail & Tolerance & 0.035 & 1163.34 \\
& Leachate & 0.044 & 967.52 \\
Wool grass & Control & 0.050 & 896.44 \\
& & & \\
& Tolerance & 0.019 & 837.85 \\
Soft stem bulrush & Leachate & 0.029 & 532.57 \\
& Control & 0.032 & 320.72 \\
& & & \\
Soft rush & Tolerance & 0.032 & 1177.02 \\
& Leachate & 0.038 & 918.94 \\
& Control & 0.043 & 746.38 \\
& & & \\
& Tolerance & 0.022 & 933.37 \\
& Leachate & 0.029 & 806.49 \\
& Control & 0.031 & 619.19 \\
\hline
\end{tabular}

or

$$
M_{M} \frac{1}{6 A^{2} B}
$$

By substituting Eq. 27 in Eq. 23, the following equation is obtained:

$$
r=\frac{1}{2.3 \mathrm{~A}^{3}\left(\frac{1}{6 \mathrm{~A}^{2} \mathrm{~B}}\right)}
$$

Eq. 28 can be rewritten as follows:

$$
r=2.61 \frac{B}{A}
$$

By substituting the value of $\mathrm{k} / 2.3$ for $\mathrm{r}$ in Eq. 29, the value of $\mathrm{k}$ can be determined as follows:

$$
\mathrm{k}=4.3839 \frac{\mathrm{B}}{\mathrm{A}}
$$

Eqs. 27 and 30 were used to determine the maximum concentrations $\left(\mathrm{M}_{\mathrm{M}}\right)$ of manganese that can be accumulated by the wetland plants and the specific uptake rates $(\mathrm{k})$, respectively. The results are shown in Table 5. The results showed that the specific Mn uptake rate is affected by the initial $\mathrm{Mn}$ concentration in the wastewater as shown in Fig. 3. As the initial Mn concentration in the wastewater increased, the specific uptake rate for each species first increased and then decreased. The plants used in this study showed signs of toxicity as the $\mathrm{k}$ value of each plant decreased with manganese concentrations above $0.41 \mathrm{mg} \mathrm{L}^{-1}$. Bould et $a l .{ }^{[30]}$ reported that toxicity to manganese varies widely between 0.5 to $200 \mathrm{mg} \mathrm{L}^{-1}$ depending on the plant species and environmental conditions. The specific Mn uptake rate for cattail was the highest followed by bulrush, soft rush and wool grass.

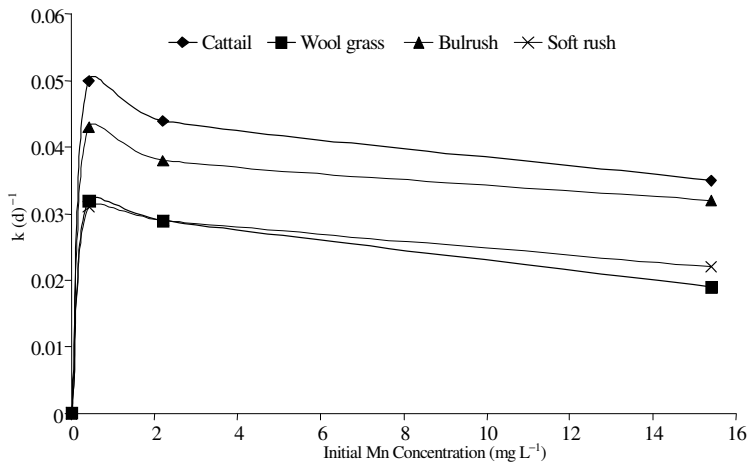

Fig. 3: Effect of initial Mn concentrations in the wastewater on the specific uptake rate

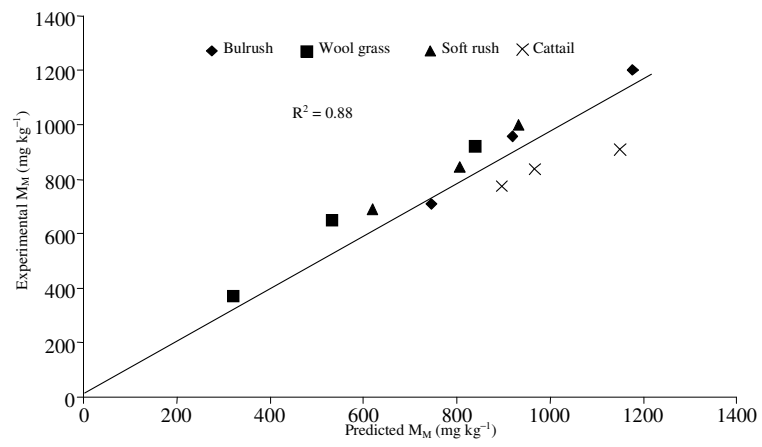

Fig. 4: Maximum predicted and experimental Mn concentrations

Similar toxicity effects were reported for other elements. Martins and Boaventura ${ }^{[31]}$ determined that as the concentration of zinc in a synthetic solution increased from 1.05 to $3.80 \mathrm{mg} \mathrm{L}^{-1}$, the uptake rate of zinc decreased from $145 \mathrm{~h}^{-1}$ to $59 \mathrm{~h}^{-1}$ in the aquatic moss F. antipyretica. The authors attributed the reduced metal uptake rate to a toxic effect on the plant. Goncalves and Boaventura ${ }^{[32]}$ studied the uptake of copper by F. antipyretica and found that the uptake rate decreased from 846 to $628 \mathrm{~h}^{-1}$ as the concentration of copper in solution increased from 0.14 to $0.60 \mathrm{mg} \mathrm{L}^{-1}$.

The model indicated that the maximum concentration of $\mathrm{Mn}\left(1177.02 \mathrm{mg} \mathrm{kg}{ }^{-1}\right.$ ) that can be accumulated by the end of the experimental period was in soft stem bulrush followed by cattail with a concentration of $1163.34 \mathrm{mg} \mathrm{kg}$, soft rush with a concentration of $933.37 \mathrm{mg} \mathrm{kg}^{-1}$ and wool grass with a concentration of $837.85 \mathrm{mg} \mathrm{kg}$. The predicted maximum concentrations were plotted against the experimental maximum concentrations obtained at the end of the experiment as shown in Fig. 4. The results showed that the model is capable of predicting the 
Am. J. Applied Sci., 5 (10): 1415-1423, 2008

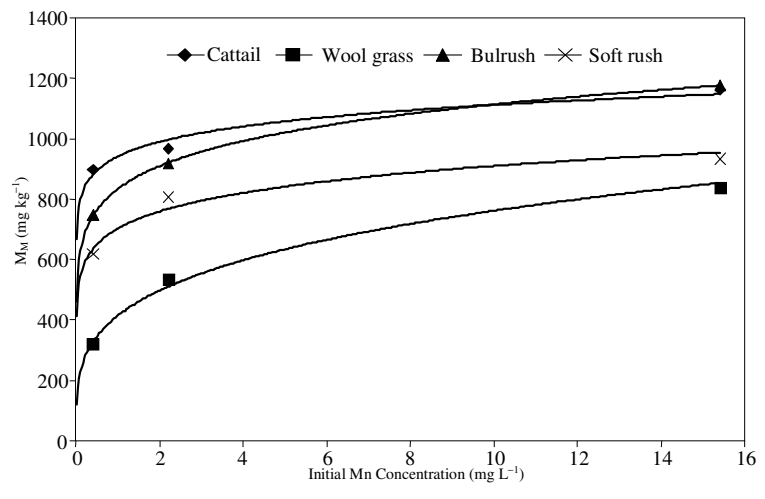

Fig. 5: Effect of initial Mn concentrations in the wastewater on the maximum Mn uptake

experimental data with relatively high confidence $\left(\mathrm{R}^{2}=0.88\right)$.

The maximum concentration of $\mathrm{Mn}$ that can be accumulated in plants is also affected by the initial $\mathrm{Mn}$ concentration as shown in Fig. 5. As the initial Mn concentration in the wastewater increased, the total Mn concentration in each species increased. Similar results were reported for other elements such as zinc, nickel and copper. Martins and Boaventura ${ }^{[31]}$ studied the uptake of zinc by the aquatic moss F. antipyretica and determined that the plant uptake capacity increased from 5046 to $10645 \mu^{-1} \mathrm{~g} \mathrm{~g}^{-1}$ as the metal concentration in the water increased from 1.05 to $3.80 \mathrm{mg} \mathrm{L}^{-1}$. Ingole and Bhole ${ }^{[33]}$ studied the uptake of heavy metals by water hyacinth and determined that as the concentration of nickel and zinc in solution increased from 5 to $25 \mathrm{mg} \mathrm{L}^{-1}$. The metal concentration in plant tissue increased from $0.223 \mathrm{mg} \mathrm{g}^{-1}$ to $0.753 \mathrm{mg} \mathrm{g}^{-1}$ and from $0.183 \mathrm{mg} \mathrm{g}^{-1}$ to $1.109 \mathrm{mg} \mathrm{g}^{-1}$, respectively. Goncalves and Boaventura ${ }^{[32]}$ studied the uptake of copper by aquatic moss $F$. antipyretica and determined that the metal concentration in water increased from $0.14 \mathrm{mg} \mathrm{L}^{-1}$ to $0.60 \mathrm{mg} \mathrm{L}^{-1}$.

\section{CONCLUSIONS}

A first order kinetic model was used to describe the uptake of Mn by two facultative (wool grass and soft rush) and two obligate (soft stem bulrush and broadleaved cattail) wetland plants. The results showed that the model is capable of predicting the experimental data with relatively high confidence $\left(\mathrm{R}^{2}=0.88\right)$. The specific Mn uptake rate and the maximum amount of Mn that can accumulate in each species were affected by the initial $\mathrm{Mn}$ concentration in the wastewater and the plant species. As the initial concentration of $\mathrm{Mn}$ in the water increased from 0.41 to $15.41 \mathrm{mg} \mathrm{L}^{-1}$, the specific Mn uptake rate of each species decreased.
Broad-leaved cattail displayed the highest specific Mn uptake rates followed by soft stem bulrush, soft rush and wool grass. As the initial Mn concentration in the water increased, the maximum amount of $\mathrm{Mn}$ that accumulated in each species increased. According to the model, soft stem bulrush plants growing in the compartment receiving wastewater with a concentration of $15.41 \mathrm{mg} \mathrm{L}^{-1}$ of $\mathrm{Mn}$ would accumulate the highest concentration of $\mathrm{Mn}$ in their tissues $\left(1177.02 \mathrm{mg} \mathrm{kg}^{-1}\right.$ ) and wool grass plants growing in the compartment receiving wastewater with a concentration of $0.41 \mathrm{mg} \mathrm{L} \mathrm{L}^{-1}$ of $\mathrm{Mn}$ would accumulate the lowest concentration of $\mathrm{Mn}$ in their tissues $\left(320.72 \mathrm{mg} \mathrm{kg}^{-1}\right)$.

\section{ACKNOWLEDGEMENTS}

This research was funded by the ELJB Foundation of Montreal.

\section{REFERENCES}

1. Cheng, S., W. Grosse, F. Karrenbrock and M. Thoennessen, 2002. Efficiency of constructed wetlands in decontamination of water polluted by heavy metals. Ecol. Eng., 18: 317-325.

2. Choudhury, J.P., M.A. Hashim and K.B. Ramachandran, 2004. Simultaneous removal of heavy metals from surface water by physiochemical treatment process. Chem. Biochem. Eng. Q., 18 (3): 174-182.

3. Charerntanyarak, L., 1999. Heavy metals removal by chemical coagulation and precipitation. Water Sci. Technol., 39 (10-11): 135-138.

4. Vendrup, M. and C. Sund, 1994. Treatment of wastewater from flue gas cleaning. Water Sci. Technol., 29 (9): 307-312.

5. Álvarez-Ayuso, E., A. García-Sánchez and X. Querol, 2003. Purification of metal electroplating waste waters using zeolites. Water Res., 37 (20): 4855-4862.

6. Vilensky, M.Y., B. Berkowitz and A. Warshawsky, 2002. In situ remediation of groundwater contaminated by heavy-and transition-metal ions by selective ion-exchange methods. Environ. Sci. Technol., 36 (8): 1851-1855.

7. Wei, G.T., Z. Yang and C.J. Chen, 2003. Room temperature ionic liquid as a novel medium for liquid/liquid extraction of metal ions. Anal. Chim. Acta, 488 (2): 183-192.

8. Woller, N., G. Subklew and M.J. Schwuger, 1996. Reactive liquid-liquid extraction of heavy metals from leachate with oil-soluble complexing surfactants. Colloids and Surfaces. A. Physiochem. Eng. Aspects, 117 (1-2): 189-200. 
9. Fisher, R., H. Seidel, D. Rahner, P. Morgenstern and C. Löser, 2004. Elimination of heavy metals from leachates by membrane electrolysis. Eng. Life Sci., 4 (5): 438-444.

10. Huang, J.S., I.C. Lee and B.J. Lin, 1993. Recovery of heavy metal from scrap metal pickling wastewater by electrolysis. Water Sci. Technol., 28 (7): 223-229.

11. Kobya, M., E. Demirbas, E. Senturk and M. Ince, 2005. Adsorption of heavy metal ions from aqueous solutions by activated carbon prepared from apricot stone. Bioresource Technol., 96 (13): 1518-1521.

12. Cervera, M.L., M.C. Arnal and M. de la Guardia, 2003. Removal of heavy metals by using adsorption on alumina or chitosan. Anal. Bioanal. Chem., 375 (6): 820-825.

13. Sela, M., J. Garty and E. Tel-Or, 1989. The accumulation and the effect of heavy metals on the water fern Azola filiculoides. New Phytol., 112 (1): 7-12.

14. Zhu, Y.L., A.M. Zayad, J.H. Qian, M. de Souza and N. Terry, 1999. Phytoaccumulation of trace elements by wetland plants II. Water hyacinth. J. Environ. Qual., 28 (1): 339-344.

15. Zurayk, R., B. Sukkariyah, R. Baalbaki and D.A. Ghanem, 2002. Ni phytoaccumulation in Mentha aquatica L. and Mentha sylvestris L. Water Air and Soil Pollution, 139 (1-4): 355-364.

16. Keskinkan, O., M.Z.L. Goksu, M. Basibuyuk and C.F. Forster, 2004. Heavy metal adsorption properties of a submerged aquatic plant (Ceratophyllum demersum). Bioresource Technol., 92 (2): 197-200.

17. Mkandawire, M. and E.G. Dudel, 2005. Accumulation of arsenic in Lemna gibba L. (duckweed) in tailing waters of two abandoned uranium mining sites in Saxony, Germany. Sci. Total Environ., 336 (1-3): 81-89.

18. Dunbabin, J.S. and K.H. Bowmer, 1992. Potential use of constructed wetlands for treatment of industrial wastewaters containing metals. Sci. Total Environ., 111 (2-3): 151-168.

19. Ye, Z.H., S.N. Whiting, Z.-Q. Lin, C.M. Lytle, J.H. Qian and N. Terry, 2001. Removal and distribution of iron, manganese, cobalt, and nickel within a Pennsylvania constructed wetland treating coal combustion by-product leachate. J. Environ. Qual., 30: 1464-1473.

20. Hammer, D.A. and R.K. Bastian, 1993. Wetlands Ecosystems: Natural Water Purifiers. In: Hammer, D.A. (Ed.). Constructed Wetlands for Wastewater Treatment: Municipal, Industrial and Agricultural. Lewis Publishers, Boca Raton, Florida, pp: 5-19.
21. Mills, J., 2003. Greenhouse manager, Department of Biology. Dalhousie University, Halifax, Nova Scotia. (Personal Communication).

22. Galbrand, C., 2004. Naturalized treatment wetlands for contaminant removal: A case study of the Burnside engineering wetland for treatment of landfill leachate. Master of Environmental Studies. Dalhousie University, Halifax, Nova Scotia.

23. Ghaly, A.E. and R. Cote, 2001. Engineered wetland technology for treatment of Industrial Park Contaminants, Technical Report, Dalhousie University, Halifax, Nova Scotia.

24. Samecka-Cymerman, A. and A.J. Kempers, 2001. Concentrations of heavy metals and plant nutrients in water, sediments and aquatic macrophytes of anthropogenic lakes (former open cut brown coal mines) differing in stage of acidification. Sci. Total Environ., 281: 87-98.

25. Collins, B.S., R.R. Sharitz and D.P. Coughlin, 2005. Elemental composition of native wetland plants in constructed mesocosm treatment wetlands. Bioresource Technol., 96: 937-948.

26. Demirezen, D. and A. Aksoy, 2006. Common hydrophytes as bioindicators of iron and manganese pollutions. Ecological Indicators, 6: 388-393.

27. Vlyssides, A.G. and D.L. Bouranis, 1998. A kinetic approach on the estimation of iron uptake by Apium nodiflorum plants. Commun. Soil Sci. Plant Anal., 29 (5-6): 561-573.

28. Stroyan, K., 1999. Calculus 2nd Edn. Academic Press Inc., Burlington, MA.

29. Vlyssides, A.G., D.L. Bouranis and M. Loizidou, 1997. A mathematical approach for the evaluation of soil conditioners eluation kinetics. Commun. Soil Sci. Plant Anal., 28 (6-8): 509-520.

30. Bould, C., E.J. Hewitt and P. Needham, 1983. Diagnosis of Mineral Disorders in Plants, Vol. 1: Principles. H.M. Stationery Office, Ministry of Agriculture, Fisheries, and Food, Agricultural Research Council, London. PP. 92, 99, 151-152.

31. Martins, R.J.E. and R.A.R. Boaventura, 2002. Uptake and release of zinc by aquatic bryophytes (Fontinalis antipyretica). Water Res., 36: 5005-5012.

32. Goncalves, E.P. and R.A.R. Boaventura, 1998. Uptake and release kinetics of copper by the aquatic moss Fontinalis antipyretica. Water Res., 12 (4): 1305-1313.

33. Ingole, N.W. and A.G. Bhole, 2003. Removal of heavy metals from aqueous solution by water hyacinth (Eichhornia crassipes). J. Water Supply Res. Technol.-AQUA, 52 (2) : 119-128. 